\title{
PENGARUH TERAPI RELAKSASI OTOT PROGRESIF TERHADAP RESPON STRES PERAWAT UGD DI UPTD PUSKESMAS SIANTAN HILIR PONTIANAK
}

\author{
Pika Romana*'Arina Nurfianti ${ }^{* *}$, Desy Wulandari**** \\ ${ }^{1}$ Program Studi Ilmu Keperawatan, Fakultas Kedokteran, Universitas Tanjungpura, \\ Jl. Prof. Dr. H. Hadari Nawawi, Pontianak \\ Email korespondensi:pikaromana21@gmail.com
}

\begin{abstract}
ABSTRAK
Latar Belakang : Stres adalah suatu emosi yang sulit untuk didefinisikan atau diukur, stress sebagai respon non spesifik tubuh terhadap sebuah tekanan reaksi fisik atau emosional tubuh terhadap peristiwa ekternal. Stres merupakan pengalaman individu yang disembunyikan melalui suatu rangsangan atau stressor, stressor adalah suatu dorangan yang menggangu yang ada didalam berbagai sistem. Salah satu upaya untuk mengatasi stress atau membuat rileks adalah dengan terapi relaksasi otot progresif. Hal ini menjadi ketertarikan peneliti karena terapi relaksasi otot progresif belum pernah dilakukan atau diberikan kepada perawat UGD di UPTD Puskesmas Siantan Hilir

Tujuan : Mengetahui pengaruh terapi relaksasi otot progresif terhadap respon stress perawat UGD di UPTD Puskesmas Siantan Hilir

Metode : Penelitian kuantitatif menggunakan Pre Experimental Design dengan kategori satu kelompok (the one group pretest and posttest design). Pada 16 perawat UGD yang mengalami respon stres. Dengan menggunakan instrument terapi relaksasi otot progresif.

Hasil : Setelah diberikan terapi relaksasi otot progresif pada perawat UGD menunjukan adanya penurunan skor respon stres. Nilai median pre test 19,50 turun menjadi 17,50 di post test, Uji Wilcoxon memberikan nilai signifikan $\mathrm{p} 0,001$

Kesimpulan : Ada pengaruh terapi relaksasi otot progresif terhadap respon stress perawat UGD di UPTD Puskesmas Siantan Hilir. Sehingga direkomendasikan menggunakan terapi relaksasi otot progresif sebagai terapi komplementer dalam mengurangi respon stres.
\end{abstract}

Kata Kunci : Responstres, relaksasi,otot progresif, NSS (Nursing Stress Scale)

Referensi : (2008-2017) 


\begin{abstract}
Background: Stress is an emotion which is difficult to define or measure, stress as a nonspecific response of the body to a pressure of the body's physical or emotional reactions to external events. Stress is an individual experience that is hidden through a stimulus or stressor, a stressor is an disturbing impuls in various systems. One of the efforts to resolving stress or make a relax is practice progressive muscle relaxation therapy. This problems became the researcher's interest because progressive muscle relaxation therapy has never been done or given to an Emergency Room (ER) nurse at UPTD Puskesmas Siantan Hilir.

Aims: To know the effect of progressive muscle relaxation therapy on stress response of nurse in emergency room at UPTD Puskesmas Siantan Hilir

Method: Quantitative research using Pre Experimental Design with one group design (the one group pretest and posttest design). At 16 ER nurses who experienced a stress response. By using the instrument of progressive muscle relaxation therapy and nursing stress scale (NSS).

Results: After practice progressive muscle relaxation therapy in for ER nurses showed a decrease in the stress response score. The median pre test value of 19.50 decreased to 17,50 in the post test, wilcoxon test gave significant value $p>0.001$

Conclusion: There is an effect of progressive muscle relaxation therapy on the stress response of nurses at the emergency room at Siantan Hilir Public Health Center. So it is recommended to use progressive muscle relaxation therapy as a complementary therapy in reducing the stress response among ER nurses
\end{abstract}

Keywords: Stress response, relaxation, progressive muscle, NSS (Nursing Stress Scale)

Reference: (2008-2017) 


\section{PENDAHULUAN}

Perubahan psikososial merupakan tekanan mental (stressor psikososial) sehingga bagi sebagian individu dapat menimbulkan perubahan dalam kehidupan dan berusaha beradaptasi untuk menanggulangginya. Menurut Pomerantz (2014). Stres dalam bahasan sehari-hari merupakan kondisi ketegangan yang kemudian mempengaruhi fisik, mental dan perilaku. Kebanyakan orang menyebut stres untuk menunjukkan pada kondisi seseorang tidak mampu mengatasi tuntutan, keinginan, harapan atau tekanan dari sekelilingnya yang berakibat pada fisik, mental maupun perilakunya. Menurut Potter \& Perry (2009). Stres merupakan hasil dari penilaian individu berkaitan dengan sumber-sumber pribadi yang dimilikinya untuk menghadapi tuntutan dari lingkungan. Respon stress dapat berupa respon fisiologis, kognitif, emosi dan perilaku.

Menurut Maxon dalam Herqutanto (2017) didapat dari data WHO (World Health Organization) menyatakan stres menjadi epidemi pada abad ke 21. National Institute of Occupational Safety and Health (NIOSH) melaporkan sekitar $40 \%$ pekerja menyatakan pekerjaan mereka penuh tekanan pada tingkat yang ekstrim. Laporan lainnya dari Attitude in American Workplace VII menyatakan $80 \%$ pekerja merasakan stres di pekerjaan mereka dan separuh membutuhkan bantuan untuk mengatasinya.

Pekerjaan seorang perawat untuk memberikan asuhan keperawatan yang komprehensif merupakan pekerjaan yang mempunyai tingkat stres yang tinggi, karena dalam bekerja perawat berhubungan langsung dengan berbagai macam pasien dengan diagnosa penyakit dalam respon yang berbeda-beda. Tugas dan tanggung jawab perawat bukan hal yang ringan untuk dipikul. Di satu sisi perawat bertanggung jawab terhadap tugas fisik, administratif dari instansi tempat perawat bekerja, menghadapi kecemasan, keluhan dan mekanisme pertahanan diri pasien yang muncul akibat sakitnya, ketegangan, kejenuhan dalam menghadapi pasien dengan kondisi kritis atau keadaan terminal. Di sisi lain perawat harus selalu dituntut untuk selalu tampil sebagai profil perawat yang baik oleh pasiennya. Berbagai situasi dan tuntutan kerja yang dialami perawat dapat menjadi sumber potensial terjadinya stres menurut Danang dalam Nurcahyani (2016).

Di UPTD Puskesmas Siantan Hilir saat ini memiliki UGD (Unit Gawat Darurat) dengan jumlah tempat tidur sebanyak 6 buah, serta dengan jumlah perawat sebanyak 17 orang. Dalam satu hari pasien yang datang atau masuk ke UGD rata-rata hampir 100 sampai 150 orang, dan itu juga termasuk pasien yang rawat jalan. Data kunjungan pasien keseluruhan di UGD dari bulan Maret-Juli 2017 sebanyak 8944 pasien, serta di UPTD Puskesmas Siantan Hilir jam kerja perawat terbagi atas 3 shift pagi, siang, dan malam dalam rata-rata 8 jam perhari menurut pernyataan kepala rungan UGD tersebut.

Menurut hasil wawancara dari 10 orang jumlah perawat, 6 orang mengatakan stres meningkat karena beban kerja. Terkadang perawat kewalahan dalam menangani pasien, bagaimana menangani pasien yang kritis atau pun desakan dari pihak keluarga pasien yang harus diutamakan untuk ditangani segera serta dengan kasus yang perlu ditangani dengan cepat, yaitu kecelakaan lalu lintas jika tidak ditangani dengan segara akan mengancam nyawa bahkan dapat menyebabkan kematian, sebagian dari pasien yang masuk di UPTD Puskesmas Siantan Hilir ini adalah pasien dengan kasus kecelakaan lalu lintas, selain itu perawat juga melayani pasien yang berobat rawat jalan Dari hasil obsevasi di dapatkan bahwa sebagian perawat tampak kelelahan saat bekerja serta perawat mengeluh stres, pusing, kelelehan, capek, kurang istirahat, sakit lambung, pegal dan nyeri pinggang karena pekerjaan. Hal yang dikeluhkan perawat tersebut merupakan gejala gangguan kesehatan yang timbul akibat stres kerja perawat UGD. 
Berdasarkan penelitian Purwaningsih (2013) tentang Hubungan Antara Beban Kerja Dengan Stres Kerja Perawat Di Instalasi Gawat Darurat RSUD Kabupaten Semarang ada hubungan antara beban kerja dan stres perawat karena beban kerja yang ditanggung oleh perawat IGD berbeda dengan diruang rawat yang lain. Perawat sangat merasa terbebani karena harus memberikan pelayanan keperawatan ekstra ketat dan cepat untuk menyelamatkan nyawa pasien. Selain itu dengan pemantauan dan pencatatan kondisi pasien secara rutin dan kontinyu juga merupakan beban tersendiri. Secara psikologis ada beban untuk dapat mempertahankan kondisi pasien supaya tidak tambah memburuk. Terhadap keluarga pasien perawat juga merasa terbebani untuk selalu menyampaikan segala kondisi pasien secara jujur, beban yang dirasakan perawat IGD akhirnya menyebabkan adanya suatu tekanan secara terus-menerus yang memicu terjadinya stres kerja.

Hasil penelitian Ronaldo (2016) tentang Hubungan Beban Kerja Perawat Dengan Waktu Tanggap Pelayanan Keperawatan Gawat Darurat Menurut Persepsi Pasien Di IGD RSUD Kabupaten Sorong didapatkan hasil bahwa faktor yang mempengaruhi beban kerja adalah jumlah pasien yang dimasukkan ke unit tiap hari, bulan, dan tahun kondisi pasien dalam unit rata- rata lama pasien tinggal di IGD dengan tindakan keperawatan langsung dan tidak langsung.

Berdasarkan penelitian Jusminar (2012) tentang Gambaran Tingkat Stres Beban Kerja Perawat Intensive Care Unit (ICU) Dirumah Sakit Kanker Dharmais didapatkan hasil bahwa tingginya tingkat stres pada perawat ICU di Rumah Sakit Kanker Dharmais disebabkan oleh bebrapa faktor, pertama perawat selalu menghadapi kondisi pasien yang kritis dan tidak stabil, kondisi tersebut dapat sebagai salah satu sumber stres pada perawat ICU. Kedua adalah tidak seimbangnya rasio perawat yang mengakibatkan perawat akan merasa kelelahan karena menangani pasien lebih dari satu. Ketiga adalah karena karaktristik pasien di Rumah Sakit Kanker Dharmais paien yang dengan penyakit kanker mempunyai masalah yang kompleks yang meliputi fisik, psikologis, sosial, spiritual, dan membutuhkan penanganan khusus.

Ada beberapa cara untuk menangani stres pada perawat, salah satuya adalah dengan melakukan terapi komplementer yaitu terapi relaksasi otot progresif. Terapi ini adalah teknik relaksasi otot dalam yang memerlukan imajinasi, ketekunan atau sugesti (Setyoadi \& Kusharyadi, 2011).

Perubahan yang diakibatkan oleh teknik relaksasi otot progesif yaitu dapat menurunkan tekanan darah, menurunkan frekuensi jantung, mengurangi disritmia jantung, mengurangi kebutuhan oksigen. Selama stres, hormon-hormon seperti epineprin, kortisol, glukagon, ACTH, kortikosteroid dan tiroid akan meningkat, stres fisik maupun emosional mengaktifkan sistem neuroendokrin dan sistem saraf simpatis melalui hipotalamus-pituitariadrenal. Teknik relaksasi otot progresif akan mengaktivasi kerja sistem saraf parasimpatis dan memanipulasi hipotalamus melalui pemusatan pikiran untuk memperkuat sikap positif sehingga rangsangan stres terhadap hipotalamus berkurang (Synder \& Lindquist 2010). Menurut Solehati \& Kosasih (2015) Relaksasi otot atau relaksasi progresif adalah suatu metode yang terdiri atas pereganggan dan relaksasi sekelompok otot, serta memfokuskan pada perasaan rileks, dan manfaat relaksasi otot progresif ini adalah untuk menurunkan ketegangan otot mengurangi tingkat kecemasan, mengurangi masalah yang berhubungan dengan stres, hipertensi, sakit kepala, nyeri, pasien yang cemas, depresi ringan, dan mengurangi insomnia.

Menurut penelitian Mustikawati (2015) tentang Efek terapi relaksasi otot progresif dalam menurunkan tingkat stres kerja pada perawat panti wredha elim di Semarang didapatkan hasil penelitian bahwa terapi relaksasi otot progresif dapat menurunkan tingkat stres kerja pada 
perawat panti wredha elim. Artinya stres kerja pada perawat panti wredha mengalami penurunan setelah diberikan terapi relaksasi otot progresif dibandingkan sebelum mengikuti terapi relaksasi otot progresif.

Berdasarkan dari data dan uraian yang penulis sampaikan maka penulis rasa penting untuk melakukan penelitian yang berjudul pengaruh terapi relaksasi otot progresif terhadap respon stres perawat UGD diPuskesmas Sungai Ambawang karena untuk menagani atau mengurangi respon stres perawat di UGD tersebut.

\section{BAHAN DAN METODE}

Desain penelitian adalah suatu model atau metode yang digunakan untuk melakukan suatu penelitian yang memberikan arah atau tujuan terhadap jalannya sebuah penelitian (Dharma, 2015). Penelitian ini adalah jenis penelitian kuantitatif dengan rancangan penelitian Pre Experimental Design. Dengan kategori satu kelompok the one group pretest and posttest design. Penelitian dilakukan dengan penilaian pemberian intervensi sebelum dan sesudah (Swarjana, 2015). Penelitian ini akan dilakukan selama 7 hari berturut-turut dengan menggunakan pengukuran Nursing Stress Scale sebelum diberikan terapi relaksasi otot progresif dan sesudah diberikan terapi relaksasi otot progresif dengan menggunakan instrumen yang sama. Populasi pada penelitian ini adalah seluruh perawat UGD di UPTD Puskesmas Siantan Hilir yang memenuhi kriteria stres adalah sebanyak 16 orang. Sampel pada penelitian ini adalah semua perawat UGD di UPTD Puskesmas Siantan Hilir yang memenuhi kriteria stres sebanyak 16 orang.

Kriteria inklusi dalam penelitian ini adalah Perawat yang berkerja di Unit Gawat Darurat. Sedangkan kriteria eksklusi dalam penelitian ini adalah Responden yang megalami ketegangan otot yang parah dan terluka, Perawat yang sedang cuti, Perawat yang tidak bersedia menjadi responden.

Variabel independen pada penelitian ini adalah Variabel dependen pada penelitian ini adalah respon stres perawat diukur dengan Nursing Stres Scale dan variabel dependen pada penelitian ini adalah Variabel independen pada penelitian ini adalah terapi relaksasi otot progresif.

Instrumen yang digunakan dalam penelitian ini adalah kuesioner dengan menggunakan Nursing Stress Scale (NSS) yang diberikan satu hari sebelum intervensi dan 1 hari setelah intervensi dari responden dikategorikan dengan nilai 0 (tidak pernah membuat stres), 1 (kadang membuat stres), 2 (berulang kali membuat stres), 3 (sangat sering membuat stres). Total skor dari kuesioner ini adalah 66.

Tempat penelitian ini dilakukan di UGD UPTD Puskesmas Siantan Hilir.. Penelitian ini telah dilaksanakan pada tanggal 18 januari 2018 sampai tanggal 28 januari 2018 .

\section{HASIL DAN PEMBAHASAN \\ Hasil}

Berdasarkan tabel 4.1 karakteristik responden berdasarkan usia terdapat 14 reponden $(87,5 \%)$ deawasa awal (26-35), dan 2 responden $(12,5 \%)$ dewasa akhir (3645), dan tidak ada responden yang berada dikategori remaja akhir (17-25) yang mengalami stres selama penelitian. Hasil penelitian karakteristik responden berdasarkan jenis kelamin terdapat 9 responden $(56,3 \%)$ laki-laki, dan 7 responden $(43,8 \%)$ perempuan, sedangkan karakteristik berdasarkan lama bekerja didapatkan hasil 13 responden $(81,3)$ lama bekerja (1-5 tahun), dan 3 responden $(18,8)$ lama bekerja ( $>5$ tahun). 
Tabel 4.1. Karakteristik responden berdasarkan usia, jenis kelamin, dan lama bekerja di UPTD Puskesmas Siantan Hilir.

\begin{tabular}{llcc}
$\begin{array}{l}\text { Karakteristik } \\
\text { responden }\end{array}$ & Remaja awal (17-25 tahun) & $\begin{array}{c}\text { Frekuensi } \\
\text { (f) }\end{array}$ & $\begin{array}{c}\text { Persentase } \\
(\%)\end{array}$ \\
\hline \multirow{3}{*}{ Usia } & 0 & $0 \%$ \\
& Dewasa awal (26-35 tahun) & 14 & $87,5 \%$ \\
\hline Jenis kelamin & Dewasa akhir (36-45 tahun) & 2 & $12,5 \%$ \\
\hline Lama bekerja & Paki-laki & 9 & $56,3 \%$ \\
& 1-5 tahun & 7 & $43,8 \%$ \\
\hline Total & $>5$ tahun & 13 & $81,3 \%$ \\
\hline Sumpuan & 3 & $18,8 \%$ \\
\hline
\end{tabular}

Tabel 4.2 Distribusi Karakteristik Responden Berdasarkan Skor Nursing Stress Scale (NSS) Terhadap Respon Stres Pre Test Dan Post Test

\begin{tabular}{lcccc}
\hline & \multicolumn{2}{c}{ Pretest } & \multicolumn{2}{c}{ Posttest } \\
\cline { 2 - 5 } Respon stres & Frekuensi & Persentase & Frekuensi & Persentase \\
& $(f)$ & $(\mathbf{\%})$ & $(f)$ & $(\%)$ \\
\hline Stres Ringan & 8 & $50,0 \%$ & 10 & $62,5 \%$ \\
\hline Stres Berat & 8 & $50,0 \%$ & 6 & $37,5 \%$ \\
\hline Total & 16 & $100 \%$ & 16 & $100 \%$ \\
\hline
\end{tabular}

Sumber : Data Primer (2017) telah diolah

Berdasarkan tabel 4.2, didapatkan hasil respon stres responden sebelum dan sesudah dilakukannya terapi relaksasi otot progresif terhadap respon stres perawat UGD di Puskesmas Siantan Hilir menggunakan Nursing Stress Scale (NSS) didapatkan hasil skor tingkat stres ringan dan stres berat sebelum diberikan terapi (pre test) yaitu stres ringan sebanyak 8 responden $(50,0 \%)$, sedangkan stres berat 8 responden $(50,0 \%)$. Tingkat respon stres ringan dan stres berat sesudah diberikan terapi (post test), yaitu stres ringan sebanyak 10 responden $(62,5 \%)$, sedangkan stres berat 6 responden $(37,5 \%)$.

Tabel 4.5Pengaruh terapi relaksasi otot progresif terhadap respon stress perawat UGD di UPTD Puskesmas Siantan Hilir.

\begin{tabular}{ccccc}
\hline Variabel & $\mathbf{I a} \boldsymbol{F}$ & A Median & SD & P Value \\
\hline $\begin{array}{cccc}\text { Respon stres } \\
\text { sebelum }\end{array}$ & 16 & 19,50 & 4,020 & \\
\hline $\begin{array}{c}\text { Respon stres } \\
\text { sesudah }\end{array}$ & 16 & 17,50 & 4,075 & 0,001 \\
\hline
\end{tabular}

Sumber : Data Primer (2017) telah diolah 
Berdasarkan tabel diatas dari 16 orang responden, dikatakan ada pengaruh terapi relaksasi otot progresif jika nilai $\mathrm{P}>0,005$ nilai median sebelum diberikannya terapi di UPTD Puskesmas Siantan Hilir yaitu 19,50 dengan standar deviasi 4,020 dan skor median setelah diberikannya terapi 17,50 dengan standar deviasi 4,075 didapatkan nilai $\mathrm{P}>0,001$. Berdasarkan data diatas dapat disimpulkan bahwa Ho ditolak dan ada pengaruh terapi relaksasi otot progresif terhadap respon stres perawat UGD di UPTD Puskesmas Siantan Hilir.

\section{Pembahasan}

Karakteristik Responden Berdasarkan Jenis Kelamin, usia, lama bekerja.

Berdasarkan hasil penelitian yang dilakukan di UPTD Puskesmas Siantan Hilir diperoleh data responden yang mengalami respon stres berdasarkan jenis kelamin yaitu laki-laki sebanyak 9 orang $(56,3 \%)$ dan perempuan sebanyak 7 orang $(43,8 \%)$. Berdasarkan data diatas disimpulkan bahwa jenis kelamin laki-laki lebih banyak mengalami respon stres dibandingkan jenis kelamin perempuan. Hal ini sejalan dengan penelitian (Mustikasari \& Mustafids, 2013) laki-laki dan perempuan memiliki perbedaan dalam merespon stres karena perempuan cenderung hilang stres setalah pekerjaan mereka selesai, dan laki-laki akan mengalami stres berkelanjutan karena tidak bisa mengeskpresikan respon stres mereka sedangkan perempuan dapat mengeskpresikan respon stres mereka misalnya dengan menangis. Jenis kelamin laki-laki cenderung lebih besar mengalami respon stres karena tugas dan tanggung jawab.

Berdasarkan penelitian yang telah dilakukan di UPTD Puskesmas Siantan Hilir didapatkan hasil responden yang mengalami stres berdasarkan usia dewasa awal (26-35 tahun) sebanyak 14 responden
(87,5\%), dan dewasa akhir (35-45 tahun) sebanyak 2 responden (12,5\%). Berdasarkan data diatas dapat disimpulkan bahwa usia yang banyak mengalami stres adalah dewasa awal, karena faktor usia berpengaruh terhadap respon stres bagaimana responden mengahadapi pasien yang gawat darurat dan kritis ditempat kerjanya, dan juga karena faktor belum lama bekerja dan belum terbiasa mengahadapi hal-hal yang terjadi ditempat kerja. Sejalan dengan penelitian (Yana, 2015) usia mempunyai pengaruh yang sangat signifikan terhadap stres, pada penelitian ini usia dewasa awal (26-35 tahun) yang mengalami stres sebanyak $75 \%$ dan dewasa akhir (36-45 tahun) yang mengalami stres sebanyak $50 \%$ faktor usia berpengaruh terhadap stres bagaimana cara agar dapat memanjemen stres saat bekerja.

Berdasarkan hasil penelitian yang dilakukan di UPTD Puskesmas Siantan Hilir diperoleh data responden yang mengalami respon stres berdasarkan lama bekerja yaitu, ada 13 reponden dengan lama bekerja (1-5 tahun) dengan jumlah persentase $(81,3 \%)$, dan ada 3 responden dengan lama bekerja ( $<5$ tahun) dengan jumlah persentase (18,8\%). Berdasarkan data diatas dapat disimpulkan bahwa lama bekerja dapat berpengaruh terhadap respon stres sesorang, dapat dilihat dari cara responden menangani pasien gawat darurat atau kritis saat bekerja responden yang bekerja (1-5 tahun) ini tampak sedikit panik dalam menangani pasien yang gawat darurat atau pun kritis dan mereka terkadang tidak bisa mengontrol emosi ketika mengatasi keluarga pasien yang datang ke ruangan tindakan, berbeda dengan responden yang telah bekerja ( $>5$ tahun) mereka terlihat sudah terbiasa mengatasi masalah ditempat kerjanya dan menghadapi keluarga pasien ketika sedang 
melakukan tindakan. Sejalan dengan penelitian (Fitri, 2013), didapatkan hasil bahwa faktor lama bekerja juga berpengaruh terhadap stres responden yang memiliki masa kerja ( $<5$ tahun) 18 orang mengalami stres $(51,4 \%)$ dan 17 orang (48,6\%) dengan masa kerja (5-7 tahun), masa kerja yang lebih lama berkaitan dengan erat dengan pengalaman dan pemahaman yang lebih baik.

Karakteristik Responden Berdasarkan pengaruh terapi relaksasi otot progresif terhadap respon stress perawat UGD di UPTD Puskesmas Siantan Hilir.

Ada pengaruh terapi relaksasi otot progresif terhadap respon stres perawat UGD di UPTD Puskesmas Siantan Hilir, yang terlihat dari penurunan skor respon stres perawat sebelum dan sesudah diberikan terapi relaksasi otot progresif. Berdasarkan hasil penelitian didapatkan hasil nilai median sebelum diberikannya terapi 19,50 dengan standar deviasi 4,020. Dan skor median setelah diberikannya terapi 17,50 dengan standar deviasi 4,075 dan didapatkan nilai $\mathrm{P}>0,001$. Berdasarkan data diatas dapat disimpulkan bahwa Ho ditolak dan ada pengaruh terapi relaksasi otot progresif terhadap respon stres perawat UGD di UPTD Puskesmas Siantan Hilir.

Berdasarkan hasil penelitian didapatkan penurunan skor respon stres perawat UGD sebelum dan sesudah diberikannya terapi relaksasi otot progresif. Penurunan skor dapat dilihat dari nilai pre test dan post test. Pada pre test 8 orang mengalami stres ringan $(50,0 \%)$ dan 8 orang juga mengalami stres berat $(50,0 \%)$ sedangkan setelah diberikan terapi relaksasi otot progresif mengalami penurunan skor pada post test 10 orang perawat $(62,5 \%)$ mengalami penurunan skor stres ringan dan 6 orang perawat $(37,5 \%)$ mengalami penurunan skor stres berat.

Berdasarkan uraian data diatas adanya penurunan respon stres pada perawat UGD di UPTD Puskesmas Siantan Hilir setelah diberikannya terapi relaksasi otot progresif karena perawat UGD di UPTD Puskesmas Siantan Hilir belum pernah diberikan terapi relaksasi otot progresif sehingga perawat sangat antusias ketika diberikan terapi, dan terapi ini diberikan setelah selesai shift dinas pada perawat setelah perawat mengalami stres pada saat bekerja dan kelelahan pada saat jam dinas, selain itu pada saat diberikan terapi perawat mengikuti instruksi peneliti dengan baik dan setelah diberikan terapi perawat mengatakan bahwa perawat merasa rileks dan nyaman.

Efek dari terapi relaksasi otot progresif ini memberikan dampak yang positif bagi para perawat karena terapi relaksasi otot progresif ini mudah dilakukan secara mandiri dan tidak menimbulkan atau menyebabkan efek samping yang menyakitkan bagi perawat. Terapi relaksasi otot progresif ini bekerja pada otot-otot tertentu mulai dari menegangkan bagian otot tangan bawah, belakang dan bisep, otot bahu, otot dahi, otot mata, otot rahang, otot mlut, otot leher bagian belakang dan depan, otot punggung, otot dada, otot perut, otot paha dan otot betis kemudian perawat merileksasikan kembali sehingga membuat otot tubuh menjadi rileks dan memberikan sensasi rileks yang nyaman bagi perawat.

Respon stres yang dialami oleh perawat karena beberapa faktor dalam lingkungan kerja membuat perawat menjadi stres, proses penyesuaian tubuh secara alamiah untuk mempertahankan keseimbangan dari berbagai faktor yang menimbulkan atau mempengaruhi keadaan menjadi tidak seimbang. Menurut teori (Kalat, 2013) stres mengaktifkan dua sistem tubuh, salah satunya adalah sistem saraf simpatik yang merpersiapkan tubuh untuk melawan atau tanggap darurat terhadap sebuah respon. Yang merespon adalah axsis hipotalamus, kelenjar pituitary, dan korteks adrenal. Aktivasi hipotalamus menginduksi kelenjar hipofisis anterior untuk mensekresi hormon adrenokortikotropik (ACTH) yang merangsang korteks adrenal manusia untuk 
mensekresi kortisol, yang meningkatkan aktivitas metabolik dan meningkatkan kadar gula darah dan nutrisi lainnya. Stres yang melepas kortisol membantu tubuh memobilisasi energinya untuk melawan situasi yang sulit dan efeknya pada jumlah dan durasi. Stres juga meningkatkan aktivitas sistem kekebalan tubuh, membantu melawan penyakit.

Sejumlah hormon juga berperan dalam respon stres. Respon hormonal yang dominan adalah aktivasi sistem $\mathrm{CRH}-$ ACTH-cortisol, kortisol membantu tubuh mengatasi stres dengan efek metabolik kortisol memecah lemak dan protein dalam tubuh dan membantuh penyebaran karbohidrat dan juga membantu meningkatkan ketersedian glukosa dalam darah. ACTH juga biasa berperan dalam menahan stres, ACTH adalah salah satu dari beberapa peptida yang memfasilitasi pembelajaran dan perilaku. Dengan demikian peningkatan ACTH selama stres psikososial dapat membantu tubuh mengatasi lebih cepat tekanan respon perilaku yang tepat (Sherwood, 2013).

Menurut teori (Rona, 2008), respon stres adalah mekanisme bertahan hidup yang berusaha mempertahankan kehidupan dalam situasi yang mengancam jiwa. Selama peristiwa yang penuh tekanan otak menandakan produksi dan pelepasan hormon. Respon otak untuk memberi energi pada tubuh seperti kenaikan kadar gula darah, detak jantung meningkat, dan tekanan darah meningkat, sehingga otot tegang untuk bereaksi.

Dengan terdapatnya penurunan skor respon stres pada penelitian ini bahwa relaksasi otot progresif efektif dapat menurunkan respon stres pada perawat UGD. Penelitian ini sejalan dengan penelitian Eko tahun 2014 bahwa relaksasi otot progresif terdapat pengaruh untuk menurunkan stres pada penelitian ini responden diambil secara acak 70 responden dengan dibagi 35 kelompok intervensi dan 35 kelompok kontrol, pada kelompok intervensi diberikan selama 6 hari perlakuan relaksasi otot progresif dan setelah diberikan perlakuan dilakukan pengukuran kembali dan dibandingkan dengan kelompok kontrol.

Berdasarkan hasil penelitian Resti tahun 2014 teknik relaksasi otot progresif adalah salah satu terapi untuk mereduksi stres, dengan membandingkan situasi pada saat tegang dan rileks. Stress adalah keadaan dimana seseorang menghadapi atau menghindari suatu pengalaman yang berupa tuntutan didalam diri seseorang, sehingga dapat diprediksi respon tubuh terhadap stressor.

Terapi relaksasi otot progresif ini akan menimbulkan efek rileks yang melibatkan saraf parasimpatis dalam sistem saraf pusat. Manusia memiliki sistem saraf pusat dan saraf otonom, sistem saraf pusat berfungsi mengendalikan gerakan-gerakan yang dikehendaki seperti gerakan tangan, kaki, leher, dan jari-jari. Sisten saraf otonom mengendalikan gerakan-gerakan yang ototmatis seperti proses kardiovaskuler dan gairah seksual. Sistem saraf ini terdiri dari dua subsitem yaitu saraf simpatis dan parasimpatis yang bekerja saling berlawanan. Jika saraf simpatis bekerja maningkatkan rangsangan atau mengacu organ-organ tubuh, meningkatkan denyut jantung dan pernapasan, serta menimbulkan penyempitan pembuluh darah tepi, maka sebaliknya dengan sistem saraf parasimpatis menstimulus turunnya semua fungsi yang dinaikan oleh saraf simpatis. Ketika individu mengalami ketegangan dan kecemasan yang bekerja adalah sistem saraf simpatis, sedangkan saat relaks yang bekerja adalah sistem saraf parasimpatis. Jadi, relaksasi otot progresif dapat mengurangi rasa stres, tegang pada otot dan cemas dengan cara merilekskan otot (Everly \& Lating, 2013).

\section{Simpulan dan Saran}

Simpulan

a. Berdasarkan karakteristik usia dari 16 responden didapatkan hasil, usia yang banyak mengalami stres adalah pada usia dewasa awal dari jumlah persentase 
usia dewasa awal (26-35 tahun) sebanyak 14 responden $(87,5 \%)$, dan dewasa akhir (35-45 tahun) sebanyak 2 responden (12,5\%). Berdasarkan karakteristik jenis kelamin dari 16 responden didapatkan hasil, jenis kelamin yang banyak mengalami respon stres adalah jenis kelamin laki-laki dengan jumlah persentase laki-laki sebanyak 9 orang $(56,3 \%)$ dan perempuan sebanyak 7 orang $(43,8 \%)$. Berdasarkan karakteristik lama bekerja dari 16 responden didapatkan hasil, responden yang mengalami respon stres berdasarkan lama bekerja yaitu, ada 13 reponden dengan lama bekerja (1-5 tahun) dengan jumlah persentase $(81,3 \%)$, dan ada 3 responden dengan lama bekerja ( $<5$ tahun) dengan jumlah persentase $(18,8 \%)$.

b. Berdasarkan Hasil dari uji wilcoxon menunjukan dikatakan ada pengaruh terapi relaksasi otot progresif jika nilai $\mathrm{P}>0,005$ nilai median sebelum diberikannya terapi di UPTD Puskesmas Siantan Hilir yaitu 19,50 dengan standar deviasi 4,020 dan skor median setelah diberikannya terapi 17,50 dengan standar deviasi 4,075 didapatkan nilai $\mathrm{P}>0,001$. Berdasarkan data diatas dapat disimpulkan bahwa Ho ditolak dan ada pengaruh terapi relaksasi otot progresif terhadap respon stres perawat UGD di UPTD Puskesmas Siantan Hilir.

\section{Saran}

1. Bagi peneliti

Bagi peneliti diharapkan dapat memanfaatkan hasil penelitian yang telah didapatkan dengan menerapkannya dalam bidang keperawatan terutama dalam hal terapi komplementer yang tepat untuk mengatasi stres pada perawat UGD. Untuk peneliti selanjutnya agar dapat melakukan penelitian dengan menggunakan kelompok kontrol sebagai pembanding.

2. Bagi Institusi Keperawatan dan Profesi Keperawatan
Peneliti berharap kepada institusi pendidikan khususnya keperawatan untuk mengadakan program atau pembelajaran mengenai terapi komplementer kepada mahasiswa keperawatan guna untuk melatih mahasiswa agar paham dan mengerti mengenai terapi komplementer

3. Bagi Rumah Sakit

Peneliti berharap bagi tempat penelitian yaitu di UPTD Puskesmas Siantan Hilir terapi ini dapat diterapkan kepada perawat UGD dan dapat diterapkan kepada pasien yang memerlukan terapi relaksasi otot progresif ini.

\section{Referensi}

1. Alfianika, N. (2016). Metode Penelitian Pengajar Bahasa Indonesia. Yogyakarta: Deepublish

2. Asmadi. (2008). Konsep Dasar Keperawatan. Jakarta: ECG

3. Azwar \& Azrul. (2010). Pengantar Administrasi

Kesehatan.

Tanggerang: Binarupa Aksara Publisher

4. Bourne, E. J. (2015). The Anxiety And Phobia Workbook (sixh edition). Canada: New Herbriger Publications

5. Darma, K.K. (2015). Metodelogi Penelitian Keperawatan. Jakarta Timur. CV. Trans Info Media

6. Davidson, M. R. (2012). A Nurses Guide To Women Mental Health. New York: Springer Publishing Company

7. Depkes RI. (2009). Kategori Usia. Jakarta

8. Eko, Apriyanto. (2015). Pengaruh Relaksasi Otot Progresif Terhadap Tingkat Stress pada Remaja di Lapas Anak Blitar. Jurnal Psikologi Indonesia: Vol. 4, No. $01: 10-21$ 
9. Everly, G.S \& Lating, J.M. (2013). A Clinical Guide to the Treatment of the Human Stress Response. New York. Springer Science

10. Fitri, M.A. (2013). Analisis FaktorFaktor Yang Berhubungan Dengan Kejadian Stres Kerja Pada Karyawan Bank. Jurnal Kesehatan Masyarakat: Vol 2

11. Herqutanto. Harsono, et all. (2013). Stres Kerja Pada Perawat Di Rumah Sakit Dan Fasilitas Pelayanan Kesehatan Primer. Jurnal Kesehatan Masyarakat: Vol 3 Hal 110-120

12. Jusminar. (2012). Gambaran Tingkat Stres Beban Kerja Perawat Intensive Care Unit (ICU) Di Rumah Sakit Kanker Dharmais. Skripsi. Universitas Indonesia

13. Kambuya, Ronaldo. (2016). Hubungan Beban Kerja Perawat Dengan Waktu Tanggap Pelayanan Keperawatan Gawat Darurat Menurut Persepsi Pasien Di IGD RSUD Kabupaten Sorong. e-journal Keperawatan (e-Kp): vol 4

14. Kalat, J.W. (2013). Biological Psychology. USA. Library of Congress.

15. Kementerian Kesehatan Republik Indonesia. (2014) Profil kesehatan Indonesia: Jakarata

16. Kementerian Kesehatan Republik Indonesia. (2011). Standar Pelayanan Keperawatan Gawat Darurat di Rumah Sakit: Jakarta

17. Laviola, G \& Macri, S. (2013). Adaptive and Maladaptive Aspects of Developmental Stress. New York. Springer Science

18. Mustikawati, Irma. (2015). Efek Terapi Relaksasi Otot Progresif Dalam Menurunkan Tingkat Stres Kerja Pada Perawat Panti Wredha Elim Di
Semarang. Tesis. Universitas Katolik Soegijapranata

19. Musliha. (2010). Keperawatan Gawat Darurat. Yogyakarta: Nuha Medika

20. Mustikawati, Mustafids. (2013). Faktor-faktor Stres Kerja Perawat Diruang IGD (Emergency Setting) DiRSUD Cibinong. Jurnal Keperawatan Jiwa: $\mathrm{Vol} 2$

21. Nurcahyani, Enny, Widodo, Rosdiana. (2016). Hubungan Tingkat Stres Kerja Dengan Kinerja Perawat. Jurnal Care: Vol 4 hal 114-117

22. Purwaningsih Puji, Ainni, Hartanti. (2013). Hubungan Antara Beban Kerja Dengan Stres Kerja Perawat Di Instalasi Gawat Darurat RSUD Kabupaten Semarang. Jurnal Managemen Keperawatan: Vol 1hal 205-209

23. Pomerantz, A. M. (2014). Psikologi Klinis IImu Pengetahuan, Praktik, dan Budaya (edisi 3). Yogyakarta: Pustaka Pelajar

24. Potter \& Perry. (2009). Fundamental Keperawatan (edisi7). Jakarta: Salemba Medika

25. Resti, Bil. I. (2014). Teknik Relaksasi Otot Progresif Untuk Mengurangi Stres Pada Penderita Asma. Jurnal Psikologi Terapan: Vol 2 hal 114-118

26. Rona, C. D. (2008). Stress Repetory Signs Ans Symtoms Stress Induced Nutrient Depletion. Library Of Congress Control

27. Ragin, D.F. (2015). Health Psychology An Interdisciplinary Approach To Health. New York. Pearson Education

28. Sari, Puspita. (2016). Pengaruh Terapi Relaksasi Otot Progresif Terhadap Tingkat Stres Dalam Menyusun Skripsi Pada Mahasiswa Program Studi Keperawatan Stikes Ngudi Waluyo 
Ungaran. Skripsi. STIKES Ngudi Waluyo Ungaran

29. Salleh, R. M. (2014). Pengendalian Stres Dan Kebimbangan, Penilaian Kognitif Dan Perilaku. Malaysia: Universitas Sains Malaysia

30. Setiadi. (2013). Konsep dan Praktik Penulisan Riset Keperawatan. Yogyakarta: Graha Ilmu

31. Sagar, Priscilla. (2012). Transcultural Nursing Theory And Models. New York: Spinger Publishing Company.

32. Setyoadi dan Kusharyadi. (2011). Terapi Modalitas Keperawatan pada Klien Psikogeriatrik. Jakarta: Salemba Medika

33. Sopiah. (2008). Perilaku organisasi. Yogyakarta : Andi

34. Solehati, Tetti \& Kosasih. (2015). Konsep Dan Aplikasi Relakasi Dalam Keperawatan Maternitas. Bandung: PT Retika Aditama

35. Solheim, J. (2016). Emergency Nursing. USA: Sigma Theta Tau Internasional

36. Suparni \& Astutik. (2016). Menopose Masalah Dan Penanganannya. Yogyakarta: CV Budi Utama
37. Sumijatun. (2010). Kosep Dasar Menuju Keperawatan Profesional. Jakarta: Trans Info Media

38. Sherwood, L. (2013). Human Physiology: From Cells to Systems. USA. Library of Congress.

39. Swarjana, I.K. (2015). Metodelogi Penelitian Kesehatan. Yogyakarta. ANDI

40. Synder \& Lindquist. (2010). Complementary/alternative terapies in nursing (fifth edition). New York: Springer Publishing Company

41. Videbeck, S.L. (2008). Buku Ajar Keperawatan Jiwa. Jakarta. EGC

42. Whersell, V.M, Harington, A, Roy. C. (2012). Generating Middle Range Theory From Evidence to Practice. USA: Springer Publihing Company

43. Williams, L. S \& Hopper, P. D. (2015). Medical Surgical Nursing. USA. Davis Compan

44. Yana, Dewi. (2015). Work Stress Among Nurses In Emergency Room in RSUD Pasar Rebo . Jurnal ARSI: Vol 2 hal 20-26. 